\title{
Factors Affecting Taxpayers' Adoption for Electronic Tax Register Machine (Etrms): The Case of Benshangul Gumuz Regional State Revenue Authority Taxpayers
}

\author{
Mohammed Ahmed Yasin \\ mame094243@gmail.com \\ Accounting and Finance Department, Assosa University, Assosa, Ethiopia
}

\begin{abstract}
The main objective of this study was examined the factors that affect taxpayers' adoption for electronic tax register machine (ETRMs) the case of Benishangul Gumuz Regional State revenue authority taxpayers. Specifically, the study empirically examined the factor of perceived usefulness, perceived risk, subjective norms, self-efficiency and timeliness on the adoption of electronics register machine of taxpayers. This study adopted explanatory research design with arrangement of primary method of data collection via questionnaires, cross-sectional, quantitative approach. The sample of this study was taken 400 taxpayers from the total population of taxpayers 2,288. Descriptive and regression analysis were performed to analyze the data using Stata version 12. Besides, econometric model estimation procedures and specification tests plus multiple regression assumptions were tested. The estimation result of the marginal effect of the probit model for the factors of taxpayers' adoption for e-tax register machine were four variables found to be significant on the probability of adoption for electronic tax register machine. The variables that become statistically significant include: perceived usefulness, perceived risk, selfefficiency and timeliness. However, subjective norms has positive but statistically insignificant relationship with adoption of electronic tax register machine. Therefore, in the case of Benishangul-Gumuz regional state taxpayer, subjective norm have not considered as a factor that affect adoption of electronic tax register machine.
\end{abstract}

Keywords: Adoption, Electronic Tax register Machine, Benishanul-Gumuze Regional State Taxpayers.

DOI: $10.7176 /$ RJFA/13-3-02

Publication date: February $28^{\text {th }} 2022$

\section{INTRODUCTION}

Tax is compulsory levy to government without expectation of direct return or benefit to tax payers. It imposes a personal obligation on the tax payer (Gerber, 2017).Governments in the world are increasing the use of information and communication technologies to improve the delivery of public services and their satisfaction. The Ethiopia government has designed a process in which information and services are electronically delivered to customers including businesses, citizens and governmental agencies (Irani et al., 2008).

Electronic tax register machine is an important service that enables taxpayers to file their tax liabilities (Hu et al., 2009). It is an important application that automates tax related processes in an attempt to improve efficiency in assessing and collecting tax information (Fu et al., 2005).By using electronic tax register machine, government can improve accuracy and efficiency over paper-based filing, lower costs, and faster refunds (Pant et al., 2004). By using electronic tax register machine service tax authorities can reduce the costs of manual data entry and processing, eliminate human errors, and reduce the turnaround time for processing income tax return (Hu et al., 2009).

The main objective of these study was examine the factors that can influence taxpayers' adoption for electronic tax register machine. Some studies (Amin, 2008, Hung et al.,2006, Hussein et al., 2010, Beneke et al., 2011, Ramayah \& Aafaqi, 2004), identified the factors that can influence the use of electronic tax register machine in other countries such as perceived usefulness, perceived risk, subjective norm, self-efficiency and timeliness. To the best of my knowledge, there has been no study conducted so far analyzing the factors affecting taxpayers' adoption for e-tax register machines in Benishangul Gumuz Regional State revenue authority tax payers. As a result this study differ from previous studies conducted in Ethiopia in identifying perceived usefulness, perceived risk, subjective norms, self-efficiency and timeliness as factors which influence taxpayers' adoption for electronic tax register machine(ETRMs) in Benishangul Gumuz Regional State revenue authority tax payers.

\section{Related Literature Review}

Electronic tax register machine have been used for sales register since long time ago in developed countries. However, the introduction of Electronic tax register machine in developing countries such as Ethiopia is a recent phenomenon. Hence, there are very few reports related to Electronic tax register machine effect on adoption of taxpayers in developing countries. Thus, the review is limited to few literature sources from the current publications. 
Electronic tax register machine service is a very specific form of electronic tax system that supports tax authority processes, work flow systems and electronic record management on the one hand, knowledge management and automated risk analysis to assess the credibility of tax returns on the other hand (Trauner, 2007). It is an important application that automates tax related processes in an attempt to improve efficiency in assessing and collecting tax information $(\mathrm{Fu}$, Chao \& Farn, 2005). By using electronic tax register machine, tax authorities can improve accuracy and efficiency over paper-based filing, lower costs, and faster refunds (Pant et al., 2004).

\section{Conceptual Frame work}

The conceptual framework was the mental picture of the relationship between the dependent variables and independent variable of the study. Therefore, a research framework is depicted in Figure 3.1 to examine factors that affecting taxpayers' adoption for e-tax register machines, where the framework postulates that self- efficiency, perceived usefulness, subjective norms, perceived risk and timeliness.

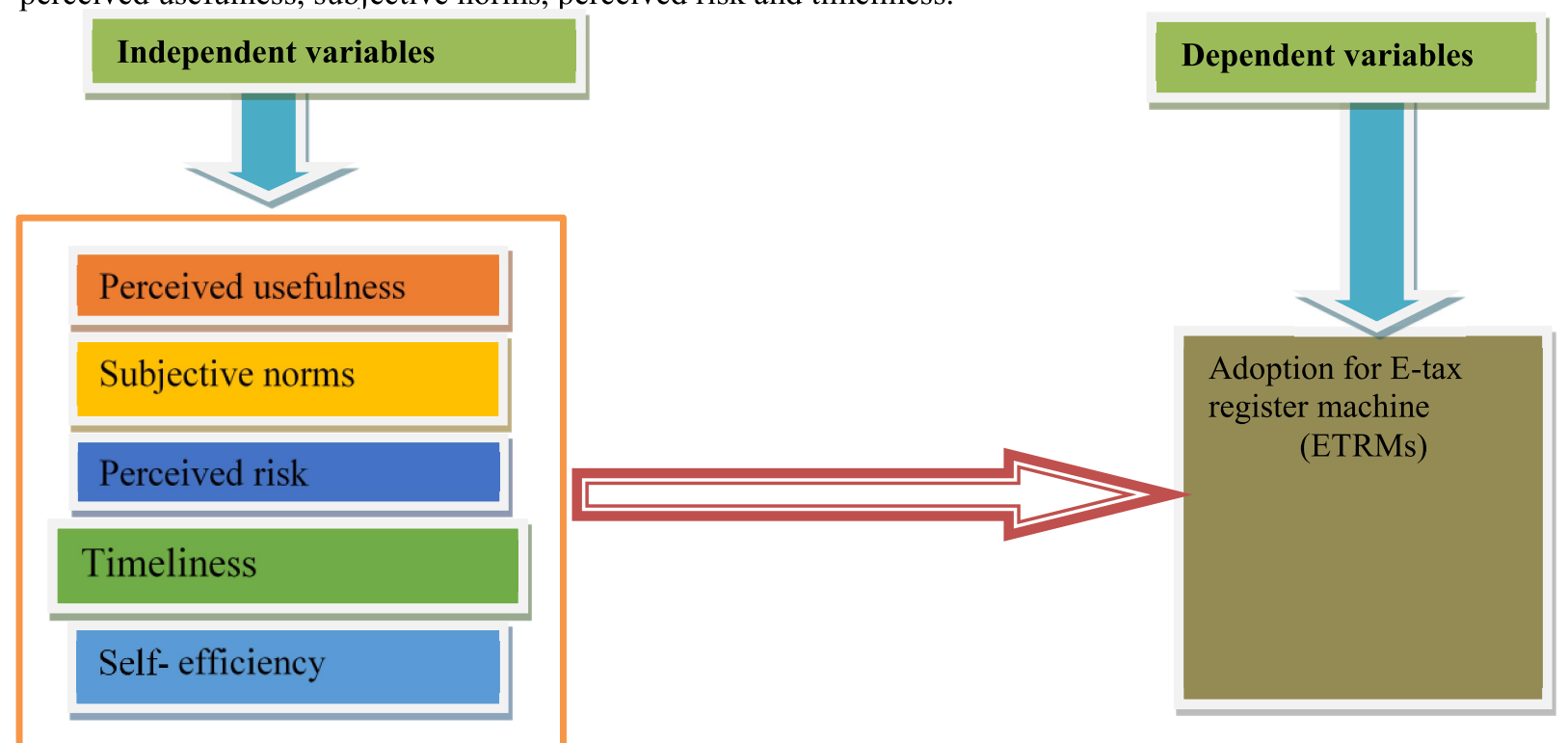

This chapter's focus on the manner in which the study had been conducted to address the objectives of the study stated in the introductory chapter. It greatly concern research approach and design, type of data and data collection techniques, sampling mechanisms including sample size, method of data analysis and measurement of variables included in the regression model and model specification.

\subsection{Research Design and Approach}

The choice of research design depends on objectives that the researchers want to achieve (Admas, 2007). The study would be used explanatory research design. Explanatory research design it examines the cause and effect relationships between dependent and independent variable (Kothari, 2004). Quantitative approach is more appropriate to achieve the purpose of this study, because it employs statistics, which is a comparative methodological discipline that uses mathematical ideas for descriptive analysis, point inference, and hypothesis testing.

\subsection{Population, Sampling and Sampling Technique}

This research targeted in Benishangul Gumuz Regional State revenue authority taxpayers, the study conducted only three Zone level category "A" and "B" taxpayers. The total number of category taxpayers is 2,288. Adopter of e-tax register machine and non-adopter are selected by using Yamane sample size determination formula in (1967) with 95percent of confidence level determination sample respondents.

Formula: $\quad n=\frac{N}{1+N(e) 2} \quad n=\frac{2,288}{1+2,228(0.05) 2}=400$

Where: $\mathrm{n}=$ sample size of adopter and non-adopter of tax payers

$\mathrm{N}=$ total number of taxpayers in the study

$\mathrm{e}=$ margin of error

Based on this formula total sample of 400 taxpayers, from e-tax register machine adopters and non-adopters are selected based on proportion of the total population. 
Table 1: Distribution of sampled respondent in the study area

\begin{tabular}{|c|c|c|}
\hline Zones & Total Category A and B taxpayers & Samples \\
\hline Assosa & 1,438 & 258 \\
\hline Metekel & 434 & 78 \\
\hline Kamashi & 356 & 64 \\
\hline Total & 2,228 & 400 \\
\hline
\end{tabular}

Source: Benishangul Gumuz Regional State Revenue Authority, (Own computation, 2018).

\subsection{Data type and source}

The study is used primary data collection techniques. The primary data are gathered from selected respondents through closed ended questionnaires. In general, the main instrument of data collection to be used is questionnaire.

4.4. Measurement of Dependent and Independent Variable.

Table 2: Summary of Measurement of Dependent and Independent Variables

\begin{tabular}{|c|c|c|c|}
\hline \multirow[b]{2}{*}{ 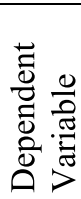 } & Variables & Symbol & Type \\
\hline & Adoption for E-tax register machine & ETRM & Dummy \\
\hline \multirow{5}{*}{ 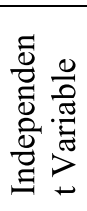 } & Self-efficiency & SE & Dummy \\
\hline & Perceived usefulness & $\mathrm{PU}$ & Dummy \\
\hline & Perceived risk & PR & Dummy \\
\hline & Subjective norm & SN & Dummy \\
\hline & Timeliness & TL & Dummy \\
\hline
\end{tabular}

Source: Own Computation

\subsection{Econometric Model specification and Data Analysis}

To conduct this research the researcher would be used the Binary logistic regression model. The study uses the dependent variable which is adoption for e-tax register machine service (ETRMs) with depending on five independent variables which are: self-efficiency of taxpayers, perceived usefulness, perceived risk, subjective norm and timeliness. In order to fulfill the desired objectives the following functional form is used.
$\mathrm{Pi}=\mathrm{f}\left(\mathrm{Z}_{1}, \mathrm{Z}_{2}, \mathrm{Z}_{3}, \mathrm{Z}_{4}\right.$$$
\mathrm{Zn})
$$

The econometric equation for the Binary logistic regression model stated in equation (2) can be specified as:

$\mathrm{Pi}=\alpha \mathrm{o}+\alpha 1 \mathrm{ETRM}+\alpha 2 \mathrm{Z2}+\alpha 3 \mathrm{Z} 3 \ldots \ldots+\alpha \mathrm{nZn}+\mu \mathrm{i}$

Where,

$$
\mathbf{Y}_{i}=\beta_{0}+\beta_{1} S_{i}+\beta_{2} P_{i^{+}}+\beta_{3} P_{i_{+}}+\beta_{4} S_{N_{i}}+\beta_{5} T_{L_{i+}}+\mu_{i}
$$

$\mathrm{Yi}=$ dichotomous variable representing adoption for electronic tax register machine; and it is equal to one if the taxpayer adopt e-tax register machine and zero otherwise.

Parameters; $\alpha 1, \alpha 2, \alpha 3 \ldots .$. anrepresents coefficients for the row vectors to be estimated, and

$E_{1}$ - Self efficiency

$\mathrm{PU}_{2}$ - Perceived Usefulness

$\mathrm{PR}_{3}$ - Perceived risk

$\mathrm{SN}_{4}$ - Subjective norm

$\mathrm{TL}_{5}$ - Timeliness

$\mu \mathrm{i}$-is the error term.

$\beta_{1}, \beta_{2},-\beta_{5}$ are the parameters estimate the coefficient of the independent variables.

\subsection{Data Analysis}

The study uses both descriptive and econometric data analysis techniques. In descriptive statistics, the demographic and socioeconomic behavior of taxpayers characteristics were explained and in econometric analysis factors that affect taxpayers' adoption for electronic tax register machine and their effect on it was analyzed by using STATA software package. Since STATA is powerful statistical software that enables us to analyze, manage, and produce graphical visualizations of data in addition to mathematical analysis. 


\section{Results of Probit Model for the factors of taxpayers adoption for e-tax register Machine}

This study employed the probit regression model to estimate and infer the parameters of the factors that affect taxpayers' adoption for electronic tax service. Out of the total five explanatory variables, output for the probit equation shows that four variables were found to be significantly affect the probability of adopting electronic tax service. Variables found to be significant included; perceived usefulness, perceived risk, self-efficiency and timeliness of e-tax service. With the above brief background, the marginal effect of the significant explanatory variables on adoption for electronic tax service is as follow.

Table 3. Maximum likelihood estimates of the binary probit model and its marginal effect on the determinants of adoption for e-tax register machine.

\begin{tabular}{|l|l|l|l|l|}
\hline Variables & Std. err. & $\mathrm{Z}$ & $\mathrm{p}>|\mathrm{z}|$ & Marginal effect \\
\hline $\mathrm{Pu}$ & 0.04448 & 3.93 & $0.000^{* * *}$ & 0.1747499 \\
\hline $\mathrm{Pr}$ & 0.05577 & -2.81 & $0.005^{* * *}$ & 0.1566222 \\
\hline $\mathrm{Sn}$ & 0.02746 & 0.37 & 0.710 & 0.0102213 \\
\hline $\mathrm{Se}$ & 0.04249 & 2.29 & $0.022^{* *}$ & 0.0973823 \\
\hline $\mathrm{Tl}$ & 0.03410 & 2.16 & $0.031^{* *}$ & 0.0736737 \\
\hline Cons. & 0.52968913 & -4.85 & $0.000^{* * *}$ & - \\
\hline
\end{tabular}

Dependent variable adoption for electronic tax service

Log pseudo likelihood

$-51.970903$

Wald chi2 (5)

43.32

Prob $>\mathrm{chi}^{2} 0.0000$

Pseudo R ${ }^{2} 0.4288$

Number of observations

400

Source: computed from own survey data, (2018)

$\mathrm{Dy} / \mathrm{dx}$ (marginal effect) is for discrete change of dummy variables from 0 to 1

Note: $* *$ and $* * *$ indicate significant at $5 \%$ and $1 \%$ level of significance respectively

Probit regression model was employed to examine the factors that affect taxpayers' adoption for e-tax service. Chi-square test was applied to statistically compare adopters of e-tax service and non-adopters for discrete explanatory variables.

\section{Conclusions}

From the estimation result of the marginal effect of the probit model for the factors of taxpayers' adoption for electronic tax register machine four variables were found to be significant on the probability of adoption for e-tax register machine. The variables that become statistically significant include: perceived usefulness, perceived risk, self-efficiency and timeliness.

Being usefulness of electronic tax register machine creates higher probability for taxpayers to adopt the service. This indicates that when the electronic tax register machine is useful as perceived, the probability of taxpayers to adopt it increases. Perceived risk also negatively and significantly associated with taxpayers' adoption for e-tax register machine. Furthermore, self-efficiency and timeliness affect taxpayers' adoption for electronic tax register machine positively and significantly. Self-efficient taxpayers to operate the system have higher probability to adopt the electronic tax register machine than those who cannot able to operate the system. Timeline electronic tax register machine also attracted taxpayers to adopt it and affect adoption for electronic tax register machine positively.

\section{REFERENCE}

Amin, B., \& Muhammad, M. ( 2007). An Analysis of mobile banking acceptance by Malaysian customers. Sunway Academic Journal , 1-12.

Amin, H. (2008). Factors affecting the intentions of customers in Malaysia to use mobile phone credit cards. . Management Research News, , 493-503.

Beneke, J., Acton, A., Richardson, D. \& White, F. (2011). E-Service Quality: an investigation of its key dimensions and the discriminatory power in the residential property sector. South Africa

Benk, S., \& Budka, T. (2011). the Acceptance of Tax Office Automation System (VEDOP) By Employees: Factorial Validation of Turkish Adapted Technology Acceptance Model.

Bernama. (2009). IRB Notes 30 Per Cent Increase In E-Filing. Retrieved Mei 1, 2009 from://www.bernama.com/bernama//v3.

Creswell, J. (2003). Research design:Qualitative,quantitative and mixed methods approaches. (2nd, Ed.) Thousand Oaks;CA:SAGE Publications.

Chang, I-Chiu, Li, Yi-Chang, Hung, Wong-Fu \& Hung, H. (2005), 'An empirical study on the impact of quality antecedents on taxpayers' acceptance of Internet tax filing systems', Government Information Quarterly, vol. 
22, no. 3, pp 389-410.

Chau, Y. \& Hu Paul J.(2002), investigating healthcare professionals' decisions to accept telemedicine technology: an empirical test of competing theories, Information and Management, Volume 39, pp. 297 - 311

Chau, Y. \& Hu, J. (2001), Information technology acceptance by individual professionals: A model comparison approach. Decision Sciences, 32(4), 699-718.

Davis, F. (1989). Perceived Usefulness, perceived Ease of use and user acceptance of information technology. 13, pp. pp 318-340.

Davis, D, Bagozzi,RP.,\&Warshaw, PR. (1989), User Acceptance of Computer Technology: A Comparison of Two Theoretical Models. Manage. Sci. 35(8): 982-1003.

ERCA. (2010). Retrieved from http://www.icfafrica.org.

ERCA. (2013). Retrieved from (http://www.2merkato.com.

ERCA. (2015). Retrieved from https://addisbiz.com.

Gujarati. (2004). Basic Econometrics, fourth edition, TATA McGraw Hill, Companies.

Hoffman, D. Novak TP \& Chatter, P. (1995), Commercial Scenarios for the Web: Opportunities and Challenges. J. Comput.-Mediated Commun. 1(3): 58-62

Hu P, Brown SA, Thong JYL, Chan FKY, \& Tam KY (2009), Determinants of Service Quality and Continuance Intention of Online Service: The Case of e-Taxpayers

Hung Shin-Yuan, Chang Chia-Ming\& Yu Ting-Jing (2006), Determinants of user acceptance of e-government services: The case of online tax filing and payment system, Government Information Quarterly, pp 97-122

Hung SY., Chang CM.,\&Yu TJ. (2006). Determinants of User Acceptance of the e-Government Services: The Case of Online Tax Filing and Payment System. Gov. Inf. Q. 23: 97-122.

Hussein, R., Mohamed, N.,Ahlan, Abd R. \& Mahmud, M. (2010)," E-government application: an integrated model on G2C adoption of online tax." Transforming Government: People, Process and Policy Vol. 5 No. 3, 2011 pp. 225-248. https://en.wikipedia.org. (n.d.). definition of taxpayer.

Ing Long, W., \& Jian-Liang, C. (2005). An extension of Trust and technology acceotance model with TPB in the initial adoption of on-line tax: An empirical study.

Irani, Z., Osman, I.H., Balci, A., Ozkan, S. \&Medeni, T.D. (2008), "Research note toward a reference process model for citizen-oriented evaluation of e-government services", Transforming Government: People, Process and Policy, Vol. 2 No. 4, pp. 297-310.

Jen-Ruei Fu, Cheng-Kiang F., \& Wen-Pin C. (2005) Acceptance of electronic tax filing: A study k2of taxpayer intentions

Johnson, N. (2009). a survey of benefits and challenges in electronic billing and payment in the Kenya power and lighting company limited, University of Nairobi, Kenya.

Kothari, C. (2004). Research Methodology: Methods and Techniques ( 2 nd ed.). New Dehli: New Age International Publishers Ltd.

Madalla, G. (1983). Limited Dependent and Qualitative Variables in Econometrics. pp. 260-285. Cambridge University Press, United Kingdom. Heckman J (1979) Sample selection bias as a specification error. pp 153161.

Malek, i. N., \& Alireza. (2011). A survey of the impact of the effective factors in adoption and application of information technology in offering electronic taxation services by taxpayers: A case study of the taxpayers.

Moyi, E., \& Ronge, E. (2006). Taxation and tax modernization in Kenya: A diagnosis of performance and options for further reform.

Mugenda, O. M. (2003). Research Methods: Quantitative and Qualitative . Nirobi.

Mukesh, A. (2011). Auditing E-taxation: Issues and Challenges, Pg 35.

Noorbakhsh, M., Akbar, B.,Shahriar,B.,Yeshan,d. \&Ali N. (2015).Electronic Payment of Taxes,.

Pant V., Stiner M.S. \& Wagner W. P. (2004). E-taxation-An introduction to the use of Tax for corporate tax reporting

Peterson RA., Balasubramanian S., Bronnenberg, BJ. (1997), Exploring the implication of the Internet for Consumer Marketing. J. Acad. Mark. Sci. 25 (4): 329-346.

Ramayah, T., \& Aafaqi, B. (2004). Role of self-efficacy in e-library usage among students of a public university in Malaysia. 1, pp39-57.

Scott M, S., \& Albaum, G. An Introduction to Marketing Research. 2010.

Sheidaei \& ShahRukh. (2012). the identification of factors affecting the acceptance of the e- system to receive tax returns using planned behavior theory, case study of the General Authority for tax affairs.

Sunahi, A. (2010). determinants of online tax payment system in Malaysia, volume 1.

Sweeney JC.,Soutar GN., Johnson LW (1999). The Role of Perceived Risk in the Quality-Value Relationship: A Study in a Retail Environment. J. Retailing 75(1): 771-705.

Tella, A., \& Olsina, G. (2014). Predicting users' continuance intention toward e-payment System. 
Teodora, V. (2008). the role of e-government in the rise of administrative efficiency, the technology acceptance model. International Journal of Information Systems \& Social Change .

Torres, L. P., \& Acrete, B. (2005). "Electronic government developments on delivering public services among EU cities", Government Information Quarterly. Vol. 22. No. 2, pp. pp 217-38.

Trauner, V. (2005). Electronic taxation: state and perspectives, series informatics. 21.

Wang, Y. (2002). The adoption of electronic tax filing Systems: An empirical Study. pp 333-352.

Webropol. (2001). Webropol training material a training held.

Woodridge. (2002). Introductory Econometrics: A modern Approach, The MIT Press, Cambridge and London.

Wooldridge, J. (2003). Introductory Econometrics. South-Western: Ohio.

Yunusa, A. (2003). Understanding the Principles and Practice of Taxation in Nigeria.

Zhao, Y., \& Saha, P. (2005). Relationship between online service quality and customer satisfaction: A study in internet banking; the case of Lulea University of Technology Sweden. 